\title{
Oviposition-site preferences of a declining butterfly Erebia medusa (Lepidoptera: Satyrinae) in nutrient-poor grasslands
}

\author{
GREGOR STUHLDREHER and THOMAS FARTMANN* \\ Department of Community Ecology, Institute of Landscape Ecology, University of Münster, Heisenbergstraße 2, 48149 Münster, \\ Germany; e-mail: gregor.stuhldreher@uni-muenster.de
}

Key words. Lepidoptera, Satyrinae, Erebia medusa, biodiversity conservation, butterfly, egg-laying, Festuca, habitat management, larval ecology, vegetation structure

\begin{abstract}
Butterflies belong to one of the most intensively studied invertebrate groups. However, detailed information on the larval ecology is still lacking in many species. This is especially true for the grass-feeding subfamily Satyrinae, to which our study species, the Woodland Ringlet (Erebia medusa Fabricius, 1787), belongs. At the habitat level, E. medusa exhibits a clear preference for abandoned grasslands with litter accumulation. In this study, we assessed the host-plant and oviposition preferences of $E$. medusa at the microhabitat level, i.e., within occupied habitat patches, in the Diemel Valley (Central Germany). Only two species of grass, Festuca ovina agg. and F. rubra agg., were systematically used for oviposition. Egg density was positively correlated with patchiness of herb layer, potential daily length of sunshine, and abandonment. However, the explanatory power of these parameters was low. We attribute this primarily to an ample supply of host plants growing under suitable conditions in the occupied habitat patches of $E$. medusa. The positive effect of abandonment is probably due to the fact that the average height of oviposition sites of $E$. medusa is greater than in most other satyrine species, which renders the eggs more vulnerable to mechanical disturbance. Moreover, thick layers of litter, which develop after the cessation of grazing or mowing, might be important as they modify the microclimate at the locations of the immature stages.
\end{abstract}

\section{INTRODUCTION}

Butterflies belong to one of the most intensively studied invertebrate groups (Thomas, 2005; Merckx et al., 2013). The state of knowledge of their biology and ecology has considerably improved in recent decades. However, detailed information concerning life-history traits and habitat requirements at different spatial scales is still lacking for many species (Dennis et al., 2006; Fartmann \& Hermann, 2006; García-Barros \& Fartmann, 2009). This is especially true for the microhabitat use of immature stages within habitat patches (e.g., host-plant and oviposition preferences) (Fartmann \& Hermann, 2006; García-Barros \& Fartmann, 2009).

The larval ecology** of butterflies in Central Europe has received rapidly growing attention since the mid-1990s (Fartmann \& Hermann, 2006). Many studies have shown that immature stages often have more specific habitat requirements than adults. This phenomenon mainly has two explanations (Fartmann \& Hermann, 2006): (i) The mobility of eggs, larvae and pupae is at best very low. Therefore, their ability to respond to quantitatively and/or qualitatively insufficient food resources or bad weather conditions by moving to more suitable places is much lower than that of adults. (ii) The adult stage constitutes only a small time fraction of the life cycle of most species, and therefore, the immature stages are exposed to the environmental conditions within their habitats for a much longer duration.
Despite the progress in recent years, knowledge of the properties and conditions (other than the taxonomic identity of the host plants) that determine the oviposition-site preferences is still incomplete (García-Barros \& Fartmann, 2009). This is at least partly because field research on the larval ecology of butterflies is complicated by the low detectability of the immature stages of many species. This is especially a major issue for satyrine butterflies (subfamily Satyrinae), whose larvae feed on grasses, have a rather inconspicuous appearance and the later larval instars mostly feed at night. Therefore, the host-plant and oviposition preferences of satyrines are generally even less well known than those of other butterfly groups (Dennis et al., 2006; García-Barros \& Fartmann, 2009). This also applies to the presently studied species, the woodland ringlet (Erebia me$d u s a$ ), a grassland butterfly that shows negative population trends in several European countries (van Swaay \& Warren, 1999).

Until recently, apart from some rather descriptive studies (Schmitt, 1993; Fartmann, 2004; Sonderegger, 2005), no systematic investigation either on the habitat preferences of E. medusa or on the species' host plants and oviposition sites had been performed. A recent survey in the Diemel Valley (Central Germany) showed that the potential of E. medusa to persist in modern landscapes is heavily constrained by habitat quality and connectivity of the patches (Stuhldreher \& Fartmann, 2014).

\footnotetext{
* Current address: Ecology Group, Department of Biology and Chemistry, University of Osnabrück, Barbarastr. 13, 49076 Osnabrück, Germany; e-mail: Thomas.Fartmann@Biologie.Uni-Osnabrueck.de

**In this paper, the term "larval ecology" is used pars pro toto to include the ecology of all the immature stages (eggs, larvae, pupae).
} 
The present study was carried out in the same area as the above-mentioned survey, but focuses on the microhabitat preferences of ovipositing females of E. medusa. Thus, it extends the knowledge of the larval ecology of satyrine butterflies.

Specifically, we aimed to answer the following questions:

(i) Do ovipositing females prefer specific conditions with respect to vegetation structure, microclimate, and land-use and vegetation type at the microhabitat level?

(ii) Do the individual host plants used for oviposition differ in their characteristics from those not oviposited upon?

\section{MATERIAL AND METHODS}

\section{Study species}

The woodland ringlet (Erebia medusa Fabricius, 1787) is a satyrine butterfly that occurs from central and south-eastern Europe eastwards to East Asia. In Central Europe, its altitudinal range extends from the lowlands to the subalpine level (Ebert \& Rennwald, 1991). E. medusa is univoltine, except in high mountain regions where it has a biennial life-cycle (Sonderegger, 2005). In our study area, it is on the wing for about four weeks, usually between the start of May and mid-June (Fartmann, 2004; pers. obs.). However, the time of adult emergence varies with weather conditions in spring. The preferred habitats of $E$. medusa are nutrient-poor grasslands and woodland glades with at most a low land-use intensity (Ebert \& Rennwald, 1991; Schraml \& Fartmann, 2013; Stuhldreher \& Fartmann, 2014). Various species of grass, namely Agrostis capillaris, Bromus erectus, Deschampsia cespitosa, D. flexuosa, Festuca ovina agg., F. rubra agg., Molinia caerulea and Nardus stricta, are believed to serve as larval host plants (Schmitt, 1993; Sonderegger, 2005; Schraml \& Fartmann, 2013); however, only F. ovina agg. and F. rubra agg. have been confirmed to be systematically used for oviposition (Fartmann, 2004). In contrast to some other satyrines, the females of $E$. medusa do not drop the eggs in the vegetation but always attach them to the host plants at relatively great heights (ca. $10 \mathrm{~cm}$ ) above ground (Schmitt, 2002; Fartmann, 2004; this study). Together with their bright white colour and their large size, this makes them easy to detect (Ebert \& Rennwald, 1991; Fartmann, 2004; Schraml \& Fartmann, 2013). E. medusa overwinters as a third instar larva at the bases of grass tussocks or in the litter layer (Sonderegger, 2005; pers. obs.). In Germany, the species is regarded as near threatened (Reinhardt \& Bolz, 2011).

\section{Study area}

The study was carried out in the Diemel Valley (Central Germany), which stretches in a west-east direction along the border between the federal states of North Rhine-Westphalia and Hesse. The study area covers approximately $100 \mathrm{~km}^{2}$ in the western part of the Diemel Valley at 230-590 $\mathrm{m}$ a.s.1. The climate there is suboceanic (Müller-Wille, 1981) with a mean annual temperature of $7.5^{\circ} \mathrm{C}$ and mean annual precipitation of $832 \mathrm{~mm}$ (all climatological values were derived from 1-km²-grid datasets of Germany's National Meteorological Service, pers. comm.).

\section{Sampling design}

From a total of 32 habitat patches where E. medusa was recorded during an extensive survey in 2010 (Stuhldreher \& Fartmann, 2014), we randomly selected 20 patches. The search for eggs of E. medusa occurred during the species' flight period in May 2011. If a patch or a part of a patch was managed, the search for eggs was always done before the patch was grazed or mown for the first time in the year. The time spent searching for eggs and the number of random samples per patch depended on the size of the patches. When searching for eggs, we randomly walked through the patches at a constant speed for one minute in small patches $(<0.46 \mathrm{ha})$, two minutes in medium-sized patches $(0.46-1 \mathrm{ha})$ and four minutes in large ( $>1 \mathrm{ha}$ ) patches. The time spent searching was measured using a stop-watch. When an egg was found, the watch was stopped and the location of the egg marked.

For every occupied host-plant individual that was found during the search, we recorded several environmental parameters (landuse and vegetation type, height and cover of all vegetation layers, abundance of the potential host plants, slope, aspect and potential daily length of sunshine) in a plot of $50 \times 50 \mathrm{~cm}$ and counted the total number of eggs within the plot. Vegetation height was measured with a folding ruler. Vegetation cover was estimated in steps of $5 \%$ (for cover values between $5 \%$ and $95 \%$ ) or $2.5 \%$ (if cover values were outside of the 5-95\% range). As potential host plants all the species of grass that are reported in the literature as oviposition substrates (see above) were considered. The slope and aspect were measured using a compass with an inclinometer. Together with the latitude of the study area $\left(51.5^{\circ} \mathrm{N}\right)$, these measurements were used to calculate the heat-load index of the plots (using equation 3 on p. 605 in McCune \& Keon, 2002). The potential daily length of sunshine was measured with an accuracy of $1 / 4$ hour for each month of the year using a horizontoscope (Tonne, 1954).

To compare the characteristics of occupied and unoccupied plots, we recorded the same parameters around randomly chosen host-plant individuals that were not oviposited upon although they grew in areas that were regularly inspected by females of E. medusa (the nearest unoccupied plant to a randomly thrown stick was recorded, cf. Anthes et al., 2003). The number of these randomly chosen unoccupied plots per patch depended on patch size: one in small, two in medium-sized and four in large patches.

We further noted plant species and the height (in $\mathrm{cm}$ ) of the occupied and unoccupied host plants. For each egg, the height above the ground, the part of the plant to which it was attached and its distance from the leaf or shoot tip were recorded.

\section{Data analysis}

Univariate significance tests were used to compare the environmental conditions of occupied and unoccupied plots, as well as the characteristics of occupied and unoccupied host plants. Metric variables were analysed using $t$ tests if data were normally distributed (Shapiro-Wilk test) with equal variances (Levene test), otherwise, Wilcoxon rank-sum tests were used. Categorical variables were analysed using Fisher's exact test. The values for height and cover of trees, shrubs and host plants other than Festuca rubra agg. and F. ovina agg. were excluded from all analyses as they had zero values in at least $95 \%$ of the samples.

A more detailed analysis of the oviposition-site preferences of E. medusa was done using Generalised Linear Mixed-effects Models (GLMMs) with a negative binomial distribution, a loglink function and Laplace approximation for parameter estimation. The number of eggs per plot was the response variable and patch was introduced as a random factor. If graphical inspection of the raw data suggested unimodal rather than linear relationships between the response and the predictor variables, centred and squared values of the predictors were entered into the full model in addition to the untransformed values. All metric predictors were checked for inter-correlations using Spearman's correlation coefficient (critical threshold $\left|r_{s}\right|>0.7$ ) before being entered into the full model (GLMM 1 in Table 4). For the litter and moss layers, the height and cover values were inter-correlated. Therefore, we multiplied height by cover and thus, in both cases obtained a single variable that indicated the amount of moss/litter 
TABLE 1. Absolute and relative frequencies of occupied and unoccupied Festuca host plants within habitats of Erebia medusa in the Diemel Valley. Differences between occupied and unoccupied host plants were analysed using Fisher's exact test $(P<0.001)$. All potential host-plant species other than Festuca rubra agg. and F. ovina agg. together only accounted for 15 (less than $10 \%$ ) of the occupied (13) and unoccupied (2) host plants. Therefore, they were excluded from the analysis.

\begin{tabular}{lccccc}
\hline \multirow{2}{*}{ Parameter } & \multicolumn{2}{c}{ Occupied $(N=96)$} & & \multicolumn{2}{c}{ Unoccupied $(N=58)$} \\
\cline { 2 - 3 } \cline { 5 - 6 } & $N$ & $\%$ & & $N$ & $\%$ \\
\hline Festuca rubra agg. & 51 & 46.8 & & 47 & 78.3 \\
Festuca ovina agg. & 45 & 41.3 & & 11 & 18.3 \\
\hline
\end{tabular}

present per plot. The categorical predictors land-use and vegetation type were not entered into the full model as they were intercorrelated with each other and with some of the metric predictors. Instead, two single-predictor models were fitted (GLMMs 2 and 3 in Table 4).

Non-significant predictors were removed from GLMM 1 by backward-elimination using likelihood ratio tests (type III tests). Only predictors that were significant at the $5 \%$ level were retained in the final model. As a model performance criterion, we used McFadden's Pseudo $R^{2}$, which can be interpreted as a goodnessof-fit measure (Menard, 2000).

All statistical analyses were done using R 2.14.1 (R Development Core Team, 2011) and the packages glmmADMB (Bolker et al., 2013) and Hmisc (Harrel Jr et al., 2013).

\section{RESULTS}

In total, we recorded 81 occupied plots with 109 occupied host plants and 144 eggs of E. medusa. Moreover, we sampled 60 unoccupied plots with 60 unoccupied host plants.

The vast majority of eggs was found on Festuca species $(N=123$ eggs, 85\%). F. ovina agg., which occurred less frequently than F. rubra agg. in the habitats of E. medusa, was used for oviposition disproportionally often (Table 1). Consequently, the numbers of eggs deposited on $F$. rubra agg. $(64,44 \%)$ and $F$. ovina agg. $(59,41 \%)$ were almost equal. Only thirteen eggs ( $9 \%)$ were found on other species of grass (Poa angustifolia: seven eggs, Agrostis stolonifera: four, Deschampsia flexuosa: one, Poa trivialis: one), although grasses other than $F$. rubra agg. and $F$. ovina agg. were abundant in the habitats of E. medusa in the Diemel Valley (especially P. angustifolia, Brachypodium pinnatum, Dactylis glomerata and Holcus lanatus). Eight eggs $(6 \%)$ were attached to dead grass leaves on the surface of the litter layer.

Females of E. medusa mostly deposited their eggs on green leaves (112 out of 144 eggs, 78\%). Eighteen eggs $(13 \%)$ were attached to dry leaves and six $(4 \%)$ to the stems of the host plants. Usually, the eggs were deposited on exterior parts of host plant leaves (mean distance from the leaf tip $\pm \mathrm{SD}=2.1 \pm 2.2 \mathrm{~cm}$ ). The height of occupied (mean $\pm \mathrm{SD}=17.8 \pm 8.4 \mathrm{~cm}$ ) and unoccupied (mean $\pm \mathrm{SD}$ $=20.1 \pm 9.6 \mathrm{~cm}$ ) host plants did not differ significantly (Wilcoxon rank sum test: $P=0.12$ ). The height of oviposition sites varied between 2 and $25 \mathrm{~cm}$ above ground, but three-quarters of the eggs were found between 7 and $14 \mathrm{~cm}$ $($ mean $\pm \mathrm{SD}=10.8 \pm 4.9 \mathrm{~cm})$.

Occupied and unoccupied plots differed with respect to the cover of the herb layer, which was significantly lower in occupied plots (Table 2). However, all other environmental parameters did not differ between occupied and unoccupied plots (Tables 2 and 3).

Similarly to the results of the significance tests, the GLMM analysis identified a significantly negative relationship between the number of eggs per plot and the cover of the herb layer (Table 4, GLMM 1). Moreover, the number of eggs per plot was negatively correlated with the centred and squared values of the mean potential daily

TABLE 2. Mean values \pm SD and minima and maxima (in brackets) of all numerical environmental parameters at occupied plots (i.e., plots that were used for egg-laying) and unoccupied plots within habitats of Erebia medusa in the Diemel Valley. Differences were analysed using $t$ tests $(t)$ or Wilcoxon rank-sum tests $(W)$. n.s. = not significant. Significant differences are in bold.

\begin{tabular}{|c|c|c|c|c|c|}
\hline \multirow{2}{*}{$\begin{array}{l}\text { Parameter } \\
\text { Vegetation characteristics }\end{array}$} & \multicolumn{2}{|c|}{ Occupied plots $(N=81)$} & \multicolumn{2}{|c|}{ Unoccupied plots $(N=60)$} & \multirow[t]{2}{*}{$P$ (test) } \\
\hline & & & & & \\
\hline \multicolumn{6}{|l|}{ Height $(\mathrm{cm})$} \\
\hline Herb layer & $18.8 \pm 7.7$ & $(5-45)$ & $20.3 \pm 9.7$ & $(5-50)$ & n.s. ${ }^{W}$ \\
\hline Mosses/lichens & $1.7 \pm 1.8$ & $(0-9)$ & $1.3 \pm 1.6$ & $(0-7)$ & n.s. ${ }^{W}$ \\
\hline Litter & $3.6 \pm 1.9$ & $(0.5-10)$ & $3.5 \pm 2.3$ & $(0-10)$ & n.s. ${ }^{W}$ \\
\hline \multicolumn{6}{|l|}{ Cover $(\%)$} \\
\hline Herb layer & $56.8 \pm 18.7$ & $(10-90)$ & $64.6 \pm 19.3$ & $(15-97.5)$ & $<\mathbf{0 . 0 5}{ }^{W}$ \\
\hline Mosses/lichens & $25.5 \pm 29.6$ & $(0-97.5)$ & $25.9 \pm 32.0$ & $(0-97.5)$ & n.s. ${ }^{W}$ \\
\hline Litter & $75.9 \pm 22.8$ & $(5-97.5)$ & $76.8 \pm 24.7$ & $(0-97.5)$ & n.s. ${ }^{W}$ \\
\hline Festuca rubra agg. & $17.5 \pm 16.9$ & $(0-65)$ & $20.1 \pm 17.9$ & $(0-75)$ & n.s. ${ }^{W}$ \\
\hline Festuca ovina agg. & $7.1 \pm 12.7$ & $(0-50)$ & $4.1 \pm 10.8$ & $(0-50)$ & n.s. ${ }^{W}$ \\
\hline Total cover of host plants & $24.6 \pm 15.8$ & $(1-65)$ & $24.2 \pm 17.2$ & $(2.5-75)$ & n.s. ${ }^{W}$ \\
\hline Bare ground & $5.8 \pm 11.9$ & $(0-50)$ & $3.9 \pm 11.3$ & $(0-60)$ & n.s. ${ }^{W}$ \\
\hline \multicolumn{6}{|l|}{ Climate characteristics } \\
\hline Heat load index (unitless) & $0.8 \pm 0.1$ & $(0.6-0.9)$ & $0.8 \pm 0.1$ & $(0.7-0.9)$ & n.s. ${ }^{t}$ \\
\hline \multicolumn{6}{|c|}{ Potential daily length of sunshine (h) } \\
\hline May/July & $11.1 \pm 1.9$ & $(4.0-14.3)$ & $11.6 \pm 1.8$ & $(7.0-15.0)$ & n.s. ${ }^{W}$ \\
\hline Annual mean & $8.5 \pm 1.4$ & $(4.6-10.9)$ & $8.8 \pm 1.7$ & $(3.0-11.0)$ & n.s. ${ }^{W}$ \\
\hline
\end{tabular}


TABLE 3. Absolute and relative frequencies of the categorical variables "land-use" and "vegetation type" at occupied and unoccupied plots within habitats of Erebia medusa in the Diemel Valley. Differences were analysed using Fisher's exact test. n.s. $=$ not significant.

\begin{tabular}{|c|c|c|c|c|c|}
\hline \multirow[t]{2}{*}{ Parameter } & \multicolumn{2}{|c|}{$\begin{array}{l}\text { Occupied plots } \\
\quad(N=81)\end{array}$} & \multicolumn{2}{|c|}{$\begin{array}{l}\text { Unoccupied } \\
\text { plots }(N=60)\end{array}$} & \multirow{2}{*}{$\begin{array}{c}P \\
\text { (test) }\end{array}$} \\
\hline & $N$ & $\%$ & $N$ & $\%$ & \\
\hline Land-use type & & & & & n.s. \\
\hline Abandoned & 61 & 75.3 & 40 & 66.7 & \\
\hline Grazing & 13 & 16.0 & 15 & 25.0 & \\
\hline Mowing & 7 & 8.6 & 5 & 8.3 & \\
\hline Vegetation type & & & & & n.s. \\
\hline Calcareous grassland & 16 & 19.8 & 7 & 11.7 & \\
\hline Mesic grassland & 62 & 76.5 & 46 & 76.7 & \\
\hline Siliceous grassland & 3 & 3.7 & 7 & 11.7 & \\
\hline
\end{tabular}

length of sunshine, indicating that the highest egg densities were recorded at plots with an average daily sunshine. The GLMMs 2 and 3 revealed significant relationships between the number of eggs per plot and land-use and vegetation type, respectively (Table 4). However, the explanatory power of all three models was very low (McFadden's Pseudo $\left.R^{2}=0.01-0.03\right)$. Nonetheless, the number of eggs per plot tended to be higher in abandoned than in grazed or mown grasslands (Fig. 1a). In semi-dry calcareous grasslands, significantly more eggs per plot were recorded than in semi-dry siliceous and mesic grasslands (Fig. 1b).

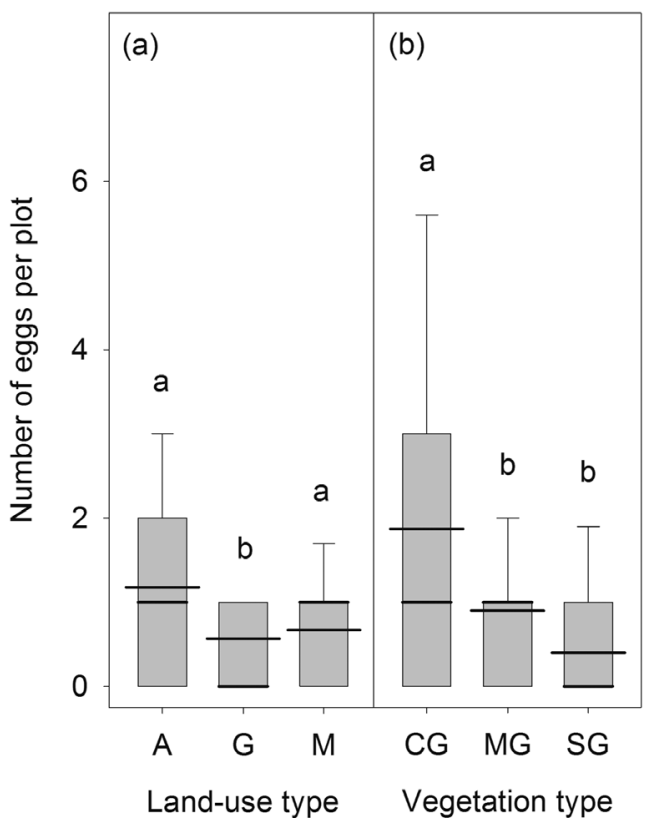

Fig. 1. Observed and predicted egg densities as a function of (a) land-use type and (b) vegetation type. Samples sizes: abandoned $(A)=101$ plots, grazing $(\mathrm{G})=28$, mowing $(\mathrm{M})=12$; calcareous grassland $(\mathrm{CG})=23$, mesic grassland $(\mathrm{MG})=108$, siliceous grassland $(\mathrm{SG})=10$. The boxplots illustrate the median, first and third quartiles and 10th/90th percentiles. The broad horizontal bars indicate the values predicted by GLMMs 2 and 3 in Table 4, respectively. Different letters indicate significant differences with respect to the group of samples that served as the baseline (abandoned and calcareous grassland, respectively, c.f. GLMMs 2 and 3 in Table 4).

TABLE 4. Results of the Generalised Linear Mixed-effects Model analyses of the association of environmental parameters with the number of eggs per plot. In GLMM 1, non-significant predictors were excluded from the final model by backward elimination $(P$-value $>0.05$ ). In all models, the significance of the predictors was assessed using likelihood ratio tests. Differences between the levels of the categorical predictors in GLMMs 2 and 3 were analysed using Wald tests. Sample size: 81 occupied and 60 unoccupied plots.

\begin{tabular}{|c|c|c|c|c|c|}
\hline GLMM & Variable & Estimate & SE & $P$ & $R_{M F}^{2}{ }^{*}$ \\
\hline \multirow[t]{12}{*}{1} & Habitat structure & & & & 0.03 \\
\hline & Intercept & 0.965 & 0.347 & & \\
\hline & Height of herb layer & . & . & n.s. & \\
\hline & Cover of herb layer & -0.014 & 0.005 & $<0.05$ & \\
\hline & Cover of herb layer (centred and squared values) & . & . & n.s. & \\
\hline & Amount of mosses/lichens ${ }^{1}$ & . & . & n.s. & \\
\hline & Amount of litter ${ }^{1}$ & . & . & n.s. & \\
\hline & Total cover of host plants & . & . & n.s. & \\
\hline & Total cover of bare ground & . & . & n.s. & \\
\hline & Heat load index & . & . & n.s. & \\
\hline & Mean potential daily length of sunshine & . & . & n.s. & \\
\hline & Mean potential daily length of sunshine (centred and squared values) & -0.080 & 0.042 & $<0.05$ & \\
\hline \multirow[t]{5}{*}{2} & Land-use & & & & 0.02 \\
\hline & Intercept & 0.161 & 0.130 & & \\
\hline & Land-use type (baseline: abandoned) & & & $<0.05$ & \\
\hline & Grazing & -0.730 & 0.310 & $<0.05$ & \\
\hline & Mowing & -0.568 & 0.436 & n.s. & \\
\hline \multirow[t]{5}{*}{3} & Vegetation & & & & 0.01 \\
\hline & Intercept & 0.626 & 0.205 & & \\
\hline & Vegetation type (baseline: calcareous grassland) & & & $<0.01$ & \\
\hline & Mesic grassland & -0.733 & 0.237 & $<0.01$ & \\
\hline & Siliceous grassland & -1.542 & 0.579 & $<0.01$ & \\
\hline
\end{tabular}

${ }^{1}$ Synthetic variable (height * cover). * Model performance based only on the explanatory power of the fixed effects. 


\section{DISCUSSION}

In this study on the egg-laying preferences of E. medusa in the Diemel Valley, only two species of grass, Festuca ovina agg. and F. rubra agg., were systematically used for oviposition. The eggs were attached to the host plants relatively high above the ground (mean height $11 \mathrm{~cm}$ ), mostly close to the leaf tips. Females preferentially deposited their eggs at microsites where the cover of the herb layer was significantly lower than at microsites that were not used for oviposition. Moreover, females preferred well-insolated microsites, although those with an extremely long daily sunshine duration tended to have lower egg density compared with slightly more shaded microsites. Egg density was higher in abandoned grasslands than in pastures or meadows, and higher in calcareous grasslands than in mesic and siliceous grasslands.

The negative correlations between the herb-layer cover and the presence of eggs and the number of eggs per plot are probably because host plants can more easily be detected in sparsely vegetated microsites and are more easily accessible for the females (García-Barros \& Fartmann, 2009). In addition to better accessibility, sparsely vegetated microsites might be preferred due to warmer microclimatic conditions. Similar patterns have been observed for Hipparchia fagi (Möllenbeck et al., 2009) and Coenonympha tullia (Weking et al., 2013) whose oviposition sites characteristically have significantly lower values for vegetation cover and density, respectively.

Among Central European butterflies, the spectrum of preferred light conditions ranges from full light (e.g., Coenonympha tullia: Weking et al., 2013; Satyrium spini: Löffler et al., 2013) to partial shade (e.g., Hamearis lucina: Fartmann, 2006; Erebia aethiops: Leopold, 2006) and almost full shade (e.g., Lopinga achine: Streitberger et al., 2012). With a mean potential daily length of sunshine of $11.1 \mathrm{~h}$ in May, E. medusa is clearly situated at the top end of this spectrum, with the corresponding values for the aforementioned species being 12.5, 11.0, 6.0, ca. 5.0 and $1.5 \mathrm{~h}$, respectively. However, the relationship between sunshine duration and the number of eggs per plot was not perfectly linear, as plots with an extremely long daily sunshine duration received fewer eggs than slightly more shaded ones. This suggests that ovipositing females of E. medusa preferred well-insolated microsites, but tended to avoid the microclimatically hottest locations. This behaviour might be related to the unusually warm spring in 2011, when our data were collected. In the study area, the mean air temperature in May 2011 was $5.7^{\circ} \mathrm{C}$ higher than the long-term (1961-90) monthly mean of $7.2^{\circ} \mathrm{C}$ (data from the weather station of Germany's National Meteorological Service in Brilon-Thülen, $0.8 \mathrm{~km}$ north of the study area).

The slightly higher egg density in abandoned grasslands agrees with the findings of a previous study at the landscape and habitat level (Stuhldreher \& Fartmann, 2014), which revealed a strong preference of E. medusa for very slightly used or abandoned grasslands with accumulations of litter. The positive effect of abandonment is probably due to the fact that the mean height of oviposition sites of
E. medusa is greater than that of most other satyrine species (see below), which renders the eggs more vulnerable to mechanical disturbance. Moreover, thick layers of litter, which develop after the cessation of grazing or mowing, might be important as they modify the microclimate in the locations of the immature stages. As all samples from calcareous grasslands originated from abandoned sites, the higher egg densities recorded in this vegetation type were possibly due to this inter-correlation between land-use and vegetation type.

Although the results of this study indicate statistically significant relationships between the presence/absence and density of eggs and several environmental parameters, the explanatory power of the statistical models was relatively low. We attribute this primarily to the ample supply of host plants growing in suitable conditions in the habitat patches occupied by E. medusa. The two host plants, F. ovina agg. and $F$. rubra agg., are widespread and abundant in nutrientpoor grasslands in the Diemel Valley (Fartmann, 2004). Consequently, Stuhldreher \& Fartmann (2014) showed that at the habitat level, host-plant abundance is not a limiting factor for the occurrence of E. medusa. The same appears to be true at the microhabitat level within occupied patches. The two host plants on average covered $25 \%$ of the plots. In addition, host plant cover, structural and microclimatic conditions were largely similar in occupied and unoccupied plots. This is because the grasslands inhabited by E. medusa are structurally very homogeneous. Varying sward heights and patches of bare soil caused by livestock grazing, which are common in more intensively used grasslands, were rarely observed in the abandoned or very slightly grazed habitats of E. medusa. Furthermore, shading by shrubs and trees was negligible as the cover of woody plants was very low at all the sites studied, due to the thick layers of litter, which prevent their germination (Ellenberg \& Leuschner, 2010). The similarity of occupied and unoccupied plots indicates that the majority of the Festuca host plants at breeding sites of E. medusa are suitable for oviposition. A contrasting situation exists for other butterfly species, for which only a small fraction of the host plants present in a patch are suitable for growth and development of the immature stages (Fartmann \& Hermann, 2006; García-Barros \& Fartmann, 2009). This is the case for, e.g., Melitaea aurelia (Eichel \& Fartmann, 2008), Argynnis niobe (Salz \& Fartmann, 2009), Polites mardon (Beyer \& Schultz, 2010), Lopinga achine (Streitberger et al., 2012) and Euphydryas desfontainii (Pennekamp et al., 2013). Those and several other species as a rule exhibit clear differences between microhabitats used for oviposition and those unoccupied. For E. medusa, however, this is not the case, probably because of the ample supply of suitable oviposition sites.

Apart from the environmental factors that were significantly correlated with egg density, the generally high values for height and cover of the litter layer, which were much higher than in more intensively used grasslands in the study area (Stuhldreher \& Fartmann, 2014), are a remarkable feature of the oviposition sites of E. medusa. Al- 
though the amount of litter did not differ between occupied and unoccupied plots within occupied patches (this study), it was the most important factor that limited the occurrence of E. medusa at the habitat level in the Diemel Valley (Stuhldreher \& Fartmann, 2014). Litter accumulation is also a striking characteristic of the habitats and oviposition sites of E. aethiops, a sibling species of E. medusa, which inhabits open woodlands (Leopold, 2006; Slamova et al., 2013), and some other satyrine species such as Coenonympha hero (Bräu \& Dolek, 2013), C. oedippus (Bräu et al., 2010; Örvössy et al., 2013; Čelik et al., 2015) and Lopinga achine (Streitberger et al., 2012). The immature stages of these species probably require a stable and relatively humid microclimate during hibernation and pupation (Leopold, 2006). The litter layer has indeed been shown to effectively minimise temperature fluctuations during winter in the habitats of E. medusa in the Diemel Valley (Stuhldreher \& Fartmann, 2014).

The vast majority of eggs were found on only two species of grass, Festuca rubra agg. and F. ovina agg., of which the latter was disproportionally more often used for oviposition. The mean cover of F. rubra agg. (19\%) was three-fold greater than that of F. ovina agg. (6\%), but the total numbers of eggs on each of these two host plants were almost equal. Fartmann (2004) already reports that $F$. ovi$n a$ agg. is the most important host plant of E. medusa in the Diemel Valley. We have two explanations for the observed preference: (i) F. ovina agg. is more suitable as a larval food, or (ii) it simply reflects the slightly different habitat requirements of these two Poaceae species. In contrast to F. rubra agg., F. ovina agg. prefers more nutrient-poor conditions and hence, grows at sites with sparser vegetation (Ellenberg \& Leuschner, 2010). Such sites were preferred by E. medusa for oviposition in this study (Tables 2 and 4). However, both assumptions require further testing.

In this study, the eggs of E. medusa were attached to the host plants relatively high above the ground (mean height $11 \mathrm{~cm}$ ), mostly close to the leaf tips. A similar pattern is recorded for two other satyrine species, Erebia aethiops (Leopold, 2006) and Coenonympha oedippus (Čelik et al., 2009). In contrast, the usual height of oviposition sites of several other Satyrinae, especially thermophilous species, is considerably lower at 1 to $2 \mathrm{~cm}$ above the ground, e.g., Chazara briseis (Leopold, 2001), Hipparchia semele (Leopold, 2007) and H. statilinus (Steiner \& Trusch, 2000). Some Satyrinae such as Aphantopus hyperantus, Melanargia galathea and Minois dryas even simply drop their eggs into the vegetation (Fartmann \& Hermann, 2006). Due to their exposed position, the eggs of E. medusa are probably more susceptible to mechanical disturbance such as mowing, grazing and trampling by livestock than the eggs of satyrines that oviposit closer to the ground. Together with the presumed importance of the litter layer as a microclimatic buffer, this might explain why E. medusa is so dependent on grasslands with a very low land-use intensity. Consistent with this hypothesis, two other satyrine species (E. aethiops and $C$. oedippus), which exhibit egg-laying patterns similar to those of $E$. medusa, are also restricted to abandoned or very slightly used habitats (Leopold, 2006; Bräu et al., 2010; Čelik \& Verovnik, 2010; Slamova et al., 2013; Čelik et al., 2015).

ACKNOWLEDGEMENTS. We are very grateful to J. Thiele (Institute of Landscape Ecology, University of Münster) for statistical advice. This work was funded by a $\mathrm{PhD}$ scholarship from the Deutsche Bundesstiftung Umwelt (DBU).

\section{REFERENCES}

Anthes N., Fartmann T., Hermann G. \& Kaule G. 2003: Combining larval habitat quality and metapopulation structure - the key for successful management of pre-alpine Euphydryas aurinia colonies. - J. Insect Conserv. 7: 175-185.

Beyer L.J. \& Schultz C.B. 2010: Oviposition selection by a rare grass skipper Polites mardon in montane habitats: advancing ecological understanding to develop conservation strategies. - Biol. Conserv. 143: 862-872.

Bolker B., Skaug H., Magnusson A. \& Nielsen A. 2013: Getting started with the glmmADMB package. https://rforge.r-project.org/scm/viewvc.php/*checkout*/pkg/inst/ doc/glmmADMB.pdf?root=glmmadmb.

BRÄU M. \& Dolek M. 2013: Wald-Wiesenvögelchen Coenonympha hero (Linneaus, 1758). In Bräu M., Bolz R., Kolbeck H., Nunner A., Voith J. \& Wolf W. (eds): Tagfalter in Bayern. Eugen Ulmer, Stuttgart, pp. 504-506.

BräU M., Dolek M. \& StetTMer C. 2010: Habitat requirements, larval development and food preferences of the German population of the False Ringlet Coenonympha oedippus (Fabricius, 1787) (Lepidoptera: Nymphalidae) - research on the ecological needs to develop management tools. - Oedippus 26: 41-51.

Čelik T. \& Verovnik R. 2010: Distribution, habitat preferences and population ecology of the False Ringlet Coenonympha oedippus (Fabricius, 1787) (Lepidoptera: Nymphalidae) in Slovenia. - Oedippus 26: 7-15.

ČElik T., VReš B. \& SelišKar A. 2009: Determinants of withinpatch microdistribution and movements of endangered butterfly Coenonympha oedippus (Fabricius, 1787) (Nymphalidae: Satyrinae). - Hacquetia 8: 115-128.

Čelik T., Bräu M., Bonelli S., Cerrato C., Vreš B., Balletto E., SteTtMer C. \& DoleK M. 2015: Winter-green host-plants, litter quantity and vegetation structure are key determinants of habitat quality for Coenonympha oedippus in Europe. - J. Insect Conserv. 19: 359-375.

Dennis R.L.H., Shreeve T.G. \& Van Dyck H. 2006: Habitats and resources: the need for a resource-based definition to conserve butterflies. - Biodivers. Conserv. 15: 1943-1966.

Ebert G. \& Rennwald E. 1991: Die Schmetterlinge BadenWürttembergs. Band 2, Tagfalter II. Eugen Ulmer, Stuttgart, $535 \mathrm{pp}$.

EicheL S. \& Fartmann T. 2008: Management of calcareous grasslands for Nickerl's Fritillary (Melitaea aurelia) has to consider habitat requirements of the immature stages, isolation, and patch area. - J. Insect Conserv. 12: 677-688.

Ellenberg H. \& Leuschner C. 2010: Vegetation Mitteleuropas mit den Alpen. Eugen Ulmer, Stuttgart, 1333 pp.

FARTMANN T. 2004: Die Schmetterlingsgemeinschaften der Halbtrockenrasen-Komplexe des Diemeltales - Biozönologie von Tagfaltern und Widderchen in einer alten Hudelandschaft. Abh. Westf. Mus. Naturk. 66(1): 256 pp.

FARTMANN T. 2006: Oviposition preferences, adjacency of old woodland and isolation explain the distribution of the Duke of Burgundy butterfly (Hamearis lucina) in calcareous grasslands in central Germany. - Ann. Zool. Fenn. 43: 335-347. 
FARTMANN T. \& HeRmann G. 2006: Larvalökologie von Tagfaltern und Widderchen in Mitteleuropa - von den Anfängen bis heute. - Abh. Westf. Mus. Naturk. 68(3/4): 11-57.

García-Barros E. \& Fartmann T. 2009: Butterfly oviposition: sites, behaviour and modes. In Settele J., Shreeve T., Konvicka M. \& Van Dyck H. (eds): Ecology of Butterflies in Europe. Cambridge University Press, Cambridge, pp. 29-42.

Harrell F.E. JR with contributions from Charles Dupont and many others 2013: Hmisc: Harrell Miscellaneous. R package version 3.13-0. http://CRAN.R-project.org/package=Hmisc.

LEOPOLD P. 2001: Schmetterlingszönosen ausgewählter Kalk-Magerrasen im Saale-Unstrut-Gebiet (Sachsen-Anhalt) unter besonderer Berücksichtigung der Habitate des Segelfalters und der Berghexe. Unpubl. Diploma thesis, Westfälische WilhelmsUniversität, Münster, 119 pp.

Leopold P. 2006: Die Larvalökologie des Waldteufels (Erebia aethiops) in Nordrhein-Westfalen und deren Bedeutung für den Erhalt der Art. - Abh. Westf. Mus. Naturk. 68(3/4): 61-82.

Leopold P. 2007: Larvalökologie der Rostbinde Hipparchia semele (Linnaeus, 1758; Lepidoptera, Satyrinae) in NordrheinWestfalen - Die Notwendigkeit raumzeitlicher Störungsprozesse für den Arterhalt. — Abh. Westf. Mus. Naturk. 69(2): 94 pp.

LÖFfler F., Stuhldreher G. \& Fartmann T. 2013: How much care does a shrub-feeding hairstreak butterfly, Satyrium spini (Lepidoptera: Lycaenidae), need in calcareous grasslands? Eur. J. Entomol. 110: 145-152.

MCCunE B. \& KeON D. 2002: Equations for potential annual direct incident radiation and heat load. - J. Veg. Sci. 13: 603-606.

Menard S. 2000: Coefficients of determination for multiple logistic regression analysis. - Am. Stat. 54: 17-24.

Merckx T., Huertas B., Basset Y. \& Thomas J. 2013: A global perspective on conserving butterflies and moths and their habitats. In Macdonald D.W. \& Willis K.J. (eds): Key Topics in Conservation Biology 2. Wiley, Oxford, pp. 237-257.

Möllenbeck V., Hermann G. \& Fartmann T. 2009: Does prescribed burning mean a threat to the rare satyrine butterfly Hipparchia fagi? Larval-habitat preferences give the answer. - $J$. Insect Conserv. 13: 77-87.

MÜLLER-WiLLE W. 1981: Westfalen. Landschaftliche Ordnung und Bindung eines Landes (2. Aufl.). Aschendorfsche Verlagsbuchhandlung, Münster, $411 \mathrm{pp}$.

Örvössy N., Körösi Á., Batáry P., VozÁr Á. \& Peregovits L. 2013: Potential metapopulation structure and the effects of habitat quality on population size of the endangered False Ringlet butterfly. - J. Insect Conserv. 17: 537-547.

Pennekamp F., Monteiro E. \& Schmitt T. 2013: The larval ecology of the butterfly Euphydryas desfontainii (Lepidoptera: Nymphalidae) in SW-Portugal: food plant quantity and quality as main predictors of habitat quality. - J. Insect Conserv. 17: 195-206.
R Development Core Team 2011: R: A Language and Environment for Statistical Computing. R Foundation for Statistical Computing, Vienna. http://www.R-project.org.

ReinhardT R. \& Bolz R. 2011: Rote Liste und Gesamtartenliste der Tagfalter (Rhopalocera) (Lepidoptera: Papilionoidea et Hesperioidea) Deutschlands. - Natursch. Biol. Vielfalt. 70: 167-194.

Salz A. \& Fartmann T. 2009: Coastal dunes as important strongholds for the survival of the rare Niobe fritillary (Argynnis niobe). - J. Insect Conserv. 13: 643-654.

Sснмітт T. 1993: Biotopansprüche von Erebia medusa brigobanna Frühstorfer, 1917 (Rundaugen-Mohrenfalter) im Nordsaarland (Lepidoptera, Nymphalidae, Satyrinae). - Atalanta 24: $33-56$.

Schmitt T. 2002: The Biology of Erebia medusa ([Denis and Schiffermüller], 1775) in Central Europe (Lepidoptera). Acta Biol. Debrec. 24: 113-129.

Schraml E. \& Fartmann T. 2013: Frühlings-Mohrenfalter Erebia medusa ([Denis \& Schiffermüller], 1775). In Bräu M., Bolz R., Kolbeck H., Nummer A., Voith J. \& Wolf W. (eds): Tagfalter in Bayern. Eugen Ulmer, Stuttgart, pp. 504-506.

Slamova I., Klecka J. \& Konvicka M. 2013: Woodland and grassland mosaic from a butterfly perspective: habitat use by Erebia aethiops (Lepidoptera: Satyridae). - Insect. Conserv. Divers. 6: 243-254.

SONDEREGGER 2005: Die Erebien der Schweiz (Lepidoptera: Satyrinae, Genus Erebia). Peter Sonderegger, Brügg bei Biel, $712 \mathrm{pp}$.

SteineR R. \& Trusch R. 2000: Eiablageverhalten und -habitat von Hipparchia statilinus in Brandenburg (Lepidoptera: Nymphalidae: Satyrinae). - Stuttg. Beitr. Naturkd. (A) 606: 1-10.

Streitberger M., Hermann G., Kraus W. \& Fartmann T. 2012: Modern forest management and the decline of the Woodland Brown (Lopinga achine) in Central Europe. - For. Ecol. Manag. 269: 239-248.

Stuhldreher G. \& Fartmann T. 2014: When habitat management can be a bad thing: effects of habitat quality, isolation and climate on a declining grassland butterfly. $-J$. Insect Conserv. 18: 965-979.

THOMAS J.A. 2005: Monitoring change in the abundance and distribution of insects using butterflies and other indicator groups. - Philos. Trans. R. Soc. Lond. (B) 360: 339-357.

Tonne F. 1954: Besser Bauen mit Besonnungs- und TageslichtPlanung. Karl Hoffmann, Schorndorf, 41 pp.

van SwaAy C.A.M. \& Warren M. 1999: Red Data Book of European Butterflies (Rhopalocera). Nature and Environment, Vol. 99, Council of Europe Publishing, Strasbourg, 260 pp.

Weking S., Hermann G. \& Fartmann T. 2013: Effects of mire type, land use and climate on a strongly declining wetland butterfly. - J. Insect Conserv. 17: 1081-1091.

Received February 18, 2015; revised and accepted April 7, 2015 Prepublished online June 4, 2015 